NBER WORKING PAPER SERIES

\title{
LAND USE CONTROLS AND THE PROVISION OF EDUCATION
}

\author{
Eric A. Hanushek \\ Kuzey Yilmaz \\ Working Paper 17730 \\ http://www.nber.org/papers/w17730 \\ NATIONAL BUREAU OF ECONOMIC RESEARCH \\ 1050 Massachusetts Avenue \\ Cambridge, MA 02138 \\ January 2012
}

We are grateful to the comments and suggestions of Charles Leung, and the seminar participants at the Fed-Philadelphia , at the 2002 Econometric Society North American Summer Meeting , at theWorkshop on Macroeconomics, Real Estate, and Public Policy at Koc University, and several conferences. The views expressed herein are those of the authors and do not necessarily reflect the views of the National Bureau of Economic Research.

NBER working papers are circulated for discussion and comment purposes. They have not been peerreviewed or been subject to the review by the NBER Board of Directors that accompanies official NBER publications.

(C) 2012 by Eric A. Hanushek and Kuzey Yilmaz. All rights reserved. Short sections of text, not to exceed two paragraphs, may be quoted without explicit permission provided that full credit, including (C) notice, is given to the source. 
Land Use Controls and the Provision of Education

Eric A. Hanushek and Kuzey Yilmaz

NBER Working Paper No. 17730

January 2012

JEL No. H4,H7,I2,J6,R2

\begin{abstract}
$\underline{\text { ABSTRACT }}$
Considerable prior analysis has gone into the study of zoning restrictions on locational choice and on fiscal burdens. The prior work on zoning - particularly fiscal or exclusionary zoning - has provided both inconclusive theoretical results and quite inconsistent empirical support of the theory. More importantly, none of this work addresses important questions about the level and distribution of public goods that are provided under fiscal zoning. Since fiscal issues and Tiebout demands are central to much of the motivation for exclusionary zoning, we expand the theoretical analysis to encompass the interplay between land use restrictions and public good provision. In this, we focus on schooling outcomes, since the provision of education is one of the primary activities of local jurisdictions. We develop a general equilibrium model of location and the provision of education. Some households create a fiscal burden, motivating the use by local governments of exclusionary land-use controls. Then, the paper analyzes what the market effects of land-use controls are and how successful they are. The policies considered (minimum lot size zoning, local public finance with a head tax, and fringe zoning) demonstrate how household behavior directly affects the equilibrium outcomes and the provision of the local public good.
\end{abstract}

Eric A. Hanushek

Hoover Institution

Stanford University

Stanford, CA 94305-6010

and NBER

hanushek@stanford.edu

Kuzey Yilmaz

University of Rochester

Rochester, NY 14627

kuyilmaz@hotmail.com 


\section{Introduction}

The primary purpose of local political jurisdictions is the provision of public goods tailored to the needs and desires of their resident populations. In his classic paper on the efficiency of local jurisdictions, Tiebout (1956) shows how choice among local areas allows households to sort themselves on the basis of demand for the public good that is provided. But this simple solution breaks down when various realities such as limited numbers of jurisdictions and finance through local property taxes are acknowledged. One important extension of the modeling of residential choice and the provision of various packages of taxes and public goods in the face of these realities has been the introduction of another empirical reality the existence of various zoning regulations. Zoning constrains the choices of households and alters the equilibrium outcomes, potentially improving the Tiebout equilibrium. By focusing entirely on the locus of taxes and expenditures across jurisdictions, this literature has, however, neglected other important aspects of the residential choices of households. Consideration of these leads to fundamental changes in the equilibrium solutions by households. This paper introduces accessibility as a second basic facet of residential location and then highlights how endogenous zoning affects the equilibrium demands for schools, the primary public good offered by local jurisdictions.

In the world of head taxes and large numbers of jurisdictions, Tiebout sorting leads to an efficient revelation of public good demands and thus supports the optimal provision of the public good. Yet, as has long been recognized, the financing of local jurisdictions through the property tax changes this solution. Some taxpayers, by buying less expensive houses within a jurisdiction, can enjoy public expenditures that exceed their contribution to revenues, creating a fiscal burden on wealthier households who must make up for this

revenue shortfall. If, however, various zoning devices can be employed, it may be possible to exclude the households that create the fiscal burdens.

Considerable prior analysis has gone into the study of various zoning restrictions on 
locational choice and on fiscal burdens. In an influential early paper, Hamilton (1975) incorporates endogenous zoning in a model where property taxes finance a local public good, and he shows that zoning allows individuals to perfectly separate themselves by income. Durlauf (1992) considers a dynamic community model in which communities impose a minimum income restriction as a requirement for residence in a community. Henderson (1980) and Epple, Romer, and Filimon (1988) analyze the endogenous choice of zoning regulations in multicommunity models, but they have no public goods. Fernandez and Rogerson (1997) study the effect of zoning regulations on allocations and welfare in a two community model. Recent theoretical work by Calabrese, Epple, and Romano (2007) and Magliocca et al. (2012) provide new theoretical structures and interesting insights. Nonetheless, the prior work on zoning - particularly fiscal or exclusionary zoning - has provided both inconclusive theoretical results and quite inconsistent empirical support of the theory (Evans (1999)). The review of the evidence by Quigley and Rosenthal (2005) provides not only a summary of the issues but ideas on how to resolve the conflicting evidence.

Three important things have been missing from this past discussion. First, it is generally assumed that residential choices are solely a function of the fiscal characteristics of a location. This yields perfect sorting across communities in terms of income and very sharp, and implausible, reactions to changes in the price of local public goods. This conclusions about homogeneous communities, however, conflicts with observations about the nature of U.S. communities. Across the school districts (communities) in the U.S., communities are quite heterogenous in terms of income (much more so than in terms of race). ${ }^{1}$ Moreover, the heterogeneity of households should not be taken as evidence that Tiebout sorting is not going on.

Second, while past work has been motivated by the provision of public goods, little is actually said about the outcomes. The demand by households for schooling outcomes drives

\footnotetext{
${ }^{1}$ See Pack and Pack $(1977,1978)$, Persky (1990), Hanushek and Yilmaz (2011).
} 
not only a portion of local residential choice but also determines the spending for schools and the variation across districts. Both spending variations and the resultant achievement differences have themselves been objects of direct public policy interventions. ${ }^{2}$

Third, a limited number of jurisdictions necessarily implies that some households will not have their ideal provision of public goods met. Additionally, restrictions on households such as the exclusionary zoning considered here will not in general move the locational equilibrium to the full Tiebout optimum.

This paper addresses each of these issues. It imbeds endogenous zoning within a multifaceted model of locational choice that allows for nonfiscal elements of location. Additionally, it focuses on the most important local public good - schools - and considers how zoning affects the level and distribution of educational outcomes.

In order to understand the interactions among these different influences on choices by households, we develop a general equilibrium model of household location and education spending decisions. This model permits new insights into the implications of fiscallymotivated land use controls. While exclusive communities can improve their educational quality through land use controls on entry, they do so at the cost of increase the overall variation in educational quality.

This paper addresses two basic questions about the exclusionary land use controls. First, to answer why cities use exclusionary land use controls, we develop a general equilibrium model of location and educational choice in which some households impose a fiscal burden on the local government. Our work is based on Hanushek and Yilmaz (2007, 2011), which provides a unified treatment of classical urban location models and Tiebout models of community choice, and finds equilibrium outcomes that are more consistent with empirical observations on community heterogeneity. Second, the paper considers the market effects of exclusionary land use controls and their distributional implications for both educational

\footnotetext{
${ }^{2}$ Hanushek and Lindseth (2010)
} 
outcomes and welfare. The policies considered in the paper are zoning, local public finance with a head tax, and fringe zoning that limits city expansion.

We present a baseline model of a monocentric city that contains two school districts whose households differ in income and tastes that reflect the value of accessibility, lot size, and public amenities (education) of a location. An absentee landlord holds an auction at each location in which households bid for that location. Each jurisdiction provides education, which is financed through property taxes on residential land. Property taxes are determined by majority voting. Households can move without a cost between jurisdictions. In equilibrium, communities are heterogenous, and some households impose a fiscal burden on the local government.

With this structure, we conduct policy experiments with different types of exclusionary land use, and then assess the outcomes in terms of the level and distribution of education. Having a more realistic model of urban structure proves to be especially important in this analysis. Public services are tied to specific locations and communities, but locations also differ in their accessibility and in their housing prices. Ignoring these aspects of location introduces a distortion in the analysis of policy alternatives, leading to very different conclusions.

This paper is organized as follows. We first develop the theoretical framework within a basic two-jurisdiction, monocentric city model. Because this model is not amenable to analytical solutions, we then calibrate this model to a protypical city and present benchmark

results. Finally, we introduce local governmental involvement through land use controls and describe the impacts of the alternative policies on households in each of the jurisdictions.

\section{A Model of Accessibility and Local Public Goods}

Consider a monocentric city on a featureless xy plane, with a Central Business district (CBD) at the origin. The firms at the CBD employ skilled and unskilled labor to produce 
a composite commodity. The firms are small so that wages in the CBD are exogenous. Moreover, the city is divided into two jurisdictions (the East School district and the West School District), and each jurisdiction operates its own schools. The y-axis, passing through the CBD, forms the boundary between the two jurisdictions. Each jurisdiction finances its schools through property taxes on residential property. Education is the only service that the local government provides in each jurisdiction.

The more common depiction of a monocentric city that has a circular central city surrounded by a donut shaped suburban ring is problematic for our analysis. ${ }^{3}$ For our purposes, however, this circular structure is problematic, because all locations at any given distance from the employment center are served by a common school district, making it difficult to see the separate influences of location and school quality. Additionally, there are empirical reasons to consider alternative depictions. The circular city is more of an analytical description than a realistic portrayal of American cities. The variety of cities that result from natural boundaries such as lakes, rivers, and mountains or from historical development patterns makes the stylized "von Thunen pattern" more a simplifying device than an accurate generalization of city structures (see Rose 1989). While it is possible to correct estimation of density gradients for missing quadrants (see Mills(1972) or Rose(1989)), the simple depiction fails in a significant number of metropolitan areas. ${ }^{4}$ Our simple city structure here is seen, for example, in Minneapolis and St. Paul, where a river divides two jurisdictions (and two school districts). This structure is not meant as a portrayal of any specific area, however, but instead is employed as the simplest way to illustrate how accessibility and

\footnotetext{
${ }^{3}$ With a circular city structure, the radial symmetry permits straightforward analytical solutions of location where it is necessary only to trace locational choices along any ray from the employment center. It has also motivated a large number of empirical analysis of urban form that are based on estimating household density functions and price gradients emanating from the center (see, for example, Mills(1972, Rose(1989), and Kim(2007)). See also de Bartolome and Ross (2003) or Cassidy, Epple, and Romer (1989). Note that our cities have some similar structure in that there is "ring-separation" of different household types within each jurisdiction.

${ }^{4} \operatorname{Kim}(2007)$ describes a number of situations where the standard depiction does not work including, importantly, the significant numbers of U.S. metropolitan areas with multiple central cities or other anomalies. Bertaud and Malpezzi (2003) also find a number of international cities are inaccurately described by smooth density gradients.
} 
public goods interact in determining the locational equilibrium. The characterization of a two-city metropolitan area also permits highlighting the implications of a limited range of jurisdictional alternatives.

One member of each household works and makes all the economic decisions in the house. Based on their earnings, households are categorized as skilled and unskilled worker households. Skilled workers make $w_{s}$ dollars per hour while unskilled workers make $w_{u}$ dollars per hour. Also, households place different values on the quality of education a jurisdiction provides. Some value education more (high valuation types), some less (low valuation types). Thus, we have four different types of households in the city $i \in\{S L, S H, U L, U H\}$ - namely Skilled Low Valuation Households (SL), Skilled High Valuation Households (SH), Unskilled Low Valuation Households (UL), and Unskilled High Valuation Households (UH). As will be clear, with just two different preference levels for education, a household that has a low valuation of education necessarily has a high valuation of accessibility.

Consider a type $i \in\{S L, S H, U L, U H\}$ household seeking a residence at a location, that is $r$ miles from the CBD in jurisdiction $\mathrm{j}$. The time endowment for the household is 24 hours. The city has a dense radial transportation system. Households commute between workplaces and residences. Commuting has both pecuniary and time costs. ${ }^{5}$ Formally, commuting requires $a / 2$ dollars and $b / 2$ hours per mile. Income is derived solely from labor. Thus, the household's income, net of transportation costs, is $Y_{i}(r)=24 w_{i}-\left(a+b w_{i}\right) r$. The preferences for households are represented by a Cobb-Douglas utility function given by $U\left(\alpha_{i}, \eta_{i} ; q, s, z, l\right)=q_{j}^{\alpha_{i}} s^{\eta_{i}} z^{\gamma} l^{\delta}$, where $\alpha_{i}+\eta_{i}+\gamma+\delta=1, \quad \mathrm{q}_{j}$ is the quality of education in community $\mathrm{j} \in\{w, e\}, s>0$ is the lot size which proxies residential quality ${ }^{6}, z>0$ is the numeraire composite commodity, $l \in[0,24]$ is leisure, $\alpha_{i} \in\left\{\alpha_{H}, \alpha_{L}\right\}$ is the taste parameter for education and, $\eta_{i} \in\left\{\eta_{H}, \eta_{L}\right\}$ is the taste parameter for lot size. The budget constraint

\footnotetext{
${ }^{5}$ Pecuniary costs of commuting are not negligible in U.S. See Altman and Desalvo (1981) for an early estimate. Internet sites offer commuting cost calculators that put the 2011 cost per mile at over $\$ 1$ (see, for example, http://commutesolutions.org/external/calc.html [accessed December 26, 2011].

${ }^{6}$ It is implicitly assumed that each household manages the construction of his house by himself and that the lot size indexes the overall quality of the residential services.
} 
of the household is given by

$$
z(r)+\left(1+\tau_{j}\right) R(r) s(r)+w_{i} l(r)=Y_{i}(r)=24 w_{i}-\left(a+b w_{i}\right) r
$$

where $\tau_{j}$ is the property tax rate, $R_{j}(r)$ is the equilibrium rent per unit of land paid to a landlord for his land in community j. Notice that this formulation suggests that households sell all available time to employers and buy back some leisure at the prevailing market wage rate.

We can define the bid-rent function of the household, which shows the household's ability to pay given a fixed utility level. The bid-rent function can be expressed mathematically as

$$
\Psi\left(r, u_{i}, q_{j}, \tau_{j}\right)=\max _{s, z, l}\left\{\frac{Y_{i}(r)-z-w_{i} l}{\left(1+\tau_{j}\right) s} \mid U\left(\alpha_{i}, \eta_{i} ; q, s, z, l\right)=u_{i}\right\}
$$

The bid-rent and bid-max lot size functions are given as

$$
\begin{aligned}
& \Psi\left(r, u_{i}, q_{j}, \tau_{j}\right)=\frac{k_{i}^{1 / \eta_{i}}}{\left(1+\tau_{j}\right) w_{i}^{\delta / \eta_{i}}} q_{j}^{\alpha_{i} / \eta_{i}} Y_{i}(r)^{\frac{\eta_{i}+\gamma+\delta}{\eta_{i}}} u_{i}^{-1 / \eta_{i}} \\
& s\left(r, u_{i}, q_{j}, \tau_{j}\right)=\frac{Y_{i}(r)}{\left(\eta_{i}+\gamma+\delta\right)\left(1+\tau_{j}\right)} \frac{Y_{i}\left(r, u_{i}, q_{j}, \tau_{j}\right)}{}
\end{aligned}
$$

where $k_{i}=\frac{\eta_{i}^{\eta_{i}} \gamma^{\gamma} \delta^{\delta}}{\left(\eta_{i}+\gamma+\delta\right)^{\left(\eta_{i}+\gamma+\delta\right)}}$ is a constant. It is easy to observe that bid-rent is convex and decreasing in distance, while bid-max lot size function is convex and increasing in distance. The land use pattern that will arise in equilibrium is determined by the relative steepness of bid-rent functions of the four different household types. In general, a steeper equilibrium bid rent curve corresponds to an equilibrium location closer to the CBD.

As in Alonso (1964), we assume a competitive land market in which households bid for land and land owners offer the land to the highest bidder. For any given location, the landlord receives five implicit offers. She may rent her land to any of our four different types of households or leave the land for a non-urban purpose (e.g. agriculture). When the latter occurs, she gets a fixed bid of $r_{a}$.

Our city is closed and home ownership relies on an absentee owner who rents houses to all households. In other words, the population of each of our four types of households are 
exogenously given. There are $\bar{N}_{S L}$ identical Skilled Low Valuation Households, $\bar{N}_{S H}$ identical Skilled High Valuation Households, $\bar{N}_{U L}$ identical Unskilled Low Valuation Households, and $\bar{N}_{U H}$ identical Unskilled High Valuation Households.

Let $L(r)$ be the land density at distance $\mathrm{r}$. By definition, the amount of land available for housing between the distance $r$ and $r+d r$ is $L(r) d r$. Since we have radial symmetry around the CBD, $L(r)$ is simply $L(r)=\pi r$ in either jurisdiction. Also, let $n_{j}(r)$ be the equilibrium density function of the household distribution in jurisdiction $j \in\{w, e\}$. That is, the number of households between the distance $r$ and $r+d r$ equals $n_{j}(r) d r$ in jurisdiction $\mathrm{j}$. Without loss of generality, let the equilibrium residence of a location at distance $r$ in jurisdiction $\mathrm{j}$ be a type i household. Then, the marginal household population at distance $r$ in community $\mathrm{j}$ is given as $n_{j}(r)=\frac{L(r)}{s\left(r, u_{i}^{*}, .\right)}$. Also, since $\bar{N}_{i} i \in\{S L, S H, U L, U H\}$, type i households reside in the city, the population constraint for type i households is stated as follows:

$$
\int_{0}^{\infty} \frac{L(r)}{S_{w}(r)} \mathrm{I}\left[t_{w}^{*}(r)=i\right] d r+\int_{0}^{\infty} \frac{L(r)}{S_{e}(r)} \mathrm{I}\left[t_{e}^{*}(r)=i\right] d r=\bar{N}_{i}
$$

Where $t_{j}^{*}(r) j \in\{w, e\}$, is a function showing the occupant of the location at distance $\mathrm{r}$ in jurisdiction $j$, in equilibrium. The indicator function, $I\left[t_{j}^{*}(r)=i\right] j \in\{w, e\}$, takes the value 1 if the equilibrium resident of location at distance $r$ in jurisdiction $\mathrm{j}$ is a type $\mathrm{i}$ household, 0 otherwise. The population constraint implicitly assumes that the land market clears in jurisdiction $j \in\{w, e\}$. Formally,

$$
S_{j}(r) n_{j}(r)=L(r) \quad \forall r \leq r_{f j}^{*}
$$

From a household's point of view, each jurisdiction is characterized by the quality of education and property tax rate pair $\left(q_{j}, \tau_{j}\right)$ it provides. Now, we turn to the question of determining $\left(q_{j}, \tau_{j}\right)$ in community $j \in\{w, e\}$. Then, the government budget constraint in community $\mathrm{j}$ is

$$
e_{j}=\tau_{j} \bar{R}_{j}=\tau_{j} \frac{\int_{0}^{r_{f j}^{*}} R_{j}(r) L(r) d r}{N_{j}}
$$


where $N_{j}$ is the population, $e_{j}$ is the expenditure per pupil, and $\bar{R}_{j}$ is the tax base per pupil in community j. Characterizing the quality of education has proved difficult. Here, to maintain comparability with the prior literature, we emphasize only educational spending, which can be interpreted as either actual quality of the schools or simply perceived quality. ${ }^{7}$ The perceived quality of education in community $\mathrm{j}$ is given by a production function

$$
q_{j}=c_{1} e_{j}^{c_{2}}
$$

where $c_{1}, c_{2}>0$ and $c_{2}<1$ are constants. Notice that the production function is concave, implying diminishing marginal returns to expenditure per pupil. The property taxes are determined by majority voting in each jurisdiction. Then, a myopic type i household at distance $\mathrm{r}$ in community j's preferred tax rate is given by the following problem:

$$
\begin{aligned}
& \max _{\tau_{j}} V(.)=\frac{k_{i}}{R(r)^{\eta i}\left(1+\tau_{j}\right)^{\eta_{i} w_{i}^{\delta}}} q_{j}^{\alpha_{i}} Y_{i}(r)^{\eta_{i}+\gamma+\delta} \quad \text { subject to } \quad q_{j}=\pi_{j}(.) e_{j} \\
& e_{j}=\tau_{j} \bar{R}_{j}
\end{aligned}
$$

Solving this problem yields the preferred tax rate for type i household, $\tilde{\tau}_{i}=\frac{\alpha_{i}}{\eta_{i}-\alpha_{i}}$. Note that the preferred tax rate is independent of income and is a function of the household's valuation type. Since there are only two valuation types for households, there are two possible preferred tax rates in the economy, and high valuation types have a higher preferred $\operatorname{tax} \operatorname{rate}\left(\tilde{\tau}_{S H}>\tilde{\tau}_{S L}\right.$ and $\left.\tilde{\tau}_{U H}>\tilde{\tau}_{U L}\right)$.

The timing of events is as follows: At the beginning of each period, Households make community/residential choice decisions with the expectation that the last period's education and property tax packages would prevail in the current period. Once they move in, they are stuck. They vote for the property tax rate in their community of residence. The public good

\footnotetext{
${ }^{7}$ Prior literature has shown that it is difficult to characterize school quality when the outcome is measured by student performance (See Hanushek $(1996,2003)$ for empirical evidence on achievement production functions). At the same time, households clearly use spending as a proxy for school quality and factor that into their locational decisions. Thus, we take a positivist view of school quality as it affects consumer behavior. In prior work, we have also considered the role of peer groups in the production function for schools (Hanushek and Yilmaz 2007, 2011). However, that formulation unduly complicates the analysis here without yielding an additional insights. Under most formulations, it will reinforce the basic fiscal forces involved, and we wish to show the operation of these forces in the simplest fiscal model.
} 
and tax rate package might be different from what they expected. Since they are immobile, they do not have much choice but to consume what the community offers for this period. At the beginning of the next period, they update their expectations, and events start over again.

Definition: An equilibrium is a set of utility levels $u_{i}^{*} \forall i \in\{S L, S H, U L, U H\}$, market rent curves $R_{j}(r) j \in\{w, e\}$, quality of education and property tax pairs $\left(q_{j}, \tau_{j}\right) j \in\{w, e\}$, household population distribution functions $n_{j}(r) j \in\{w, e\}$, and types functions $t_{j}^{*}(r)$ $j \in\{w, e\}$ which show the equilibrium occupant of the location at distance $\mathrm{r}$ in community j such that

- Different household types bid for each location. The land at a location is developed for the highest bidder if the highest bid exceeds the fixed non-urban purpose bid of $r_{a}$. Otherwise, it is not developed.

- All job opportunities are offered by a firm located at the CBD. Wages in the CBD are exogenously determined. The city has a dense radial commuting system. Households commute to workplaces. Commuting has both pecuniary and time costs.

- Regardless of their location or communities, households of the same type attain the same utility level. (I.e., in equilibrium a type i household gets $u_{i}^{*}$ everywhere)

- The city contains two jurisdictions, each of which operates its own schools. Moreover, it is a closed city (i.e. populations for each types are exogenous) and the land is owned by absentee landlords.

- The local public good, education, is produced through a production function, and is financed through local property taxes on residential land, determined by majority voting in each jurisdiction.

- Labor and land markets clear. 


\begin{tabular}{|c|c|c|c|}
\hline Parameter & Value & Parameter & Value \\
\hline$\alpha_{H}$ & 0.016 & $\eta_{H}$ & 0.034 \\
\hline$\alpha_{L}$ & 0.013 & $\eta_{L}$ & 0.037 \\
\hline$\gamma$ & 0.2 & $\delta$ & 0.75 \\
\hline$a$ & $\$ 1$ & $b$ & $0.13 \mathrm{hrs}$ \\
\hline$w_{s}$ & $\$ 19$ & $w_{u}$ & $\$ 10$ \\
\hline$c_{1}$ & 3.66 & $c_{2}$ & 0.84 \\
\hline
\end{tabular}

Table 1: Calibration Parameters

- The local government budget balances in all jurisdictions.

\section{Calibration of the Urban Economy}

The model is calibrated to match some key stylized facts of a typical skilled high valuation (SH) household and a typical middle size city in the U.S. in which she lives.

The hourly wages for unskilled and skilled workers are calibrated as $w_{u} \approx 10$ and $w_{s} \approx 18$, respectively. These number are obtained from the fact that in the U.S., average weekly hours of persons working full time is about 40 hours $^{8}$, and the average annual earnings of 18 year or over high school and college graduate workers are $\$ 22,154$ and $\$ 38,112$, respectively in 1997 . Assuming the household works for 40 hours a week, the share of leisure in the household's budget is $\frac{\delta}{\eta_{H}+\gamma+\delta}=1-\frac{40 w_{s}}{24 \times 7 \times w_{s}} \approx 0.76$. The data on average annual expenditures of some selected MSAs suggest that a household spends about one-fifth of its income on shelter. Therefore, the budget share of composite commodity and land are set to be $\frac{\gamma}{\eta_{H}+\gamma+\delta}=$ $(1-0.76) \times 0.8 \approx 0.19$ and $\frac{\eta_{H}}{\eta_{H}+\gamma+\delta}=(1-0.76) \times 0.2 \approx 0.048$, respectively. Moreover, recall that the preferred tax rate for a type i household is given by $\tilde{\tau}_{i}=\frac{\alpha_{i}}{\eta_{i}-\alpha_{i}}$ and we had two possible preferred tax rates, one for high valuation and another for low valuation type households. The one for high (low) valuation type is set to be about 2.2 percent (1.3 percent). These values are sufficient to permit calibration of $\alpha_{H}, \alpha_{L}, \eta_{H}, \eta_{L}, \gamma, \delta$.

The pecuniary commuting cost per round trip mile is based on the cost of owning and operating an automobile. In 1997, pecuniary cost per mile was 53.08 cents, suggesting a

\footnotetext{
${ }^{8}$ The statistical facts, unless otherwise indicated, come from the Statistical Abstract of the United States, 1998.
} 
pecuniary commuting cost of $a=\$ 1$ per round trip mile. Assuming the commuting speed is 15 miles per hour within the city, the time cost of commuting per round trip mile is set to be $b=0.13$ hours.

In equilibrium, the endogenous urban fringe distance is set at about 10 miles in both jurisdictions. The population of the city is set to be 1,500,000 households, which implies approximately a population density of 8,000 households per square mile ${ }^{9}$. Approximately, 40 percent of the total population is assumed to be skilled worker households. Moreover, 25 percent of skilled households are assumed to be low valuation type. As for the unskilled households, 75 percent are low valuation types.

The agricultural rent bid $r_{a}$ is set to be $\$ 6,850$ per acre per year. The parameters of the education production function are set to be $c_{1}=3.66, c_{2}=0.84$ so that $\left(q_{j}, \tau_{j}\right)$ preferences of households in jurisdiction $j \in\{w, e\}$ are consistent with $\left(q_{j}, \tau_{j}\right)$ pairs that induce the desired population distribution.

\section{Benchmark Results}

In equilibrium, households of each type form a concentric ring, or zone, within each of the two jurisdictions around the employment center, and zones for all household types are ranked by the distance from the city center in the order of steepness of their bid-rent functions. The results for the benchmark equilibrium are shown in Table 2 and Figures 1 through 3. Our results are quite consistent with the residential pattern observed in the United States. In both cities, households with higher incomes typically locate farther from the CBD, occupying larger dwellings than households with lower incomes. Moreover, for each income group, those with high valuation of education live further from the center than those with low valuation of education (i.e., those with high valuation of accessibility).

These patterns are shown for the East city in figures 1 and 2. (Note that the labeling of

\footnotetext{
${ }^{9}$ The median population per square mile of cities with 200,000 or more population was 3,546 in 1992 . Source: County and City Data Book, 1994.
} 


\begin{tabular}{|r|r|r|}
\hline \multicolumn{1}{|c|}{ Types } & \multicolumn{1}{|c|}{ West } & \multicolumn{1}{c|}{ East } \\
\hline School Quality & 11.5 & 15 \\
\hline Tax Rate & $1.35 \%$ & $2.22 \%$ \\
\hline Skilled Low & 8.2 & 1.8 \\
\hline Skilled High & 9.3 & 20.7 \\
\hline Unskilled Low & 29 & 16.1 \\
\hline Unskilled High & 2.3 & 12.6 \\
\hline
\end{tabular}

Table 2: Benchmark Distribution of Population and School Quality

the two cities is arbitrary). The price of land varies across locations with distance due to commuting costs, as in a standard urban location model. The West city follows the same general pattern (not shown), although the rents at any given distance from the employment center will be lower because of the lower school quality (discussed below). Across communities the quality of education and property taxes differ, and in equilibrium households are indifferent to living in either jurisdiction. This differences in rents across jurisdictions is nothing but the capitalization of accessibility and differing quality of education.

The communities are heterogenous in both income and tastes, and all types are present in both communities (Table 2). ${ }^{10}$ (The table gives the distribution of households by jurisdiction as a percent of the total population in both jurisdictions). This heterogeneity of communities is the result of the two components of a location: access to employment and school quality. All households of a given type in terms of income and tastes for education are happy with their residential location in equilibrium, but some of each type will end up purchasing more access and less schooling in trading off the two at equilibrium prices. This aspect of the model introduces a realism that is important in judging policy alternatives that differentially affect the two communities.

In our baseline model, Table 2 shows that the East School district provides the best education and is the community of choice for most of the high valuation households, whether of high or low income (skill) level. This better education does come with a higher price tag,

\footnotetext{
${ }^{10}$ Note that there is a trivially different equilibrium where East and West are simply switched. In each case, however, our prior work shows that the solution converges on the same equilibrium, independent of the starting point chosen, when there are no peer effects in the educational production function. See Hanushek and Yilmaz (2007).
} 
namely higher property taxes than the West School District, but this is the majority vote equilibrium of the households.

Following Hamilton (1975), we have concentrated on property taxes to fund our local education, as consistent with U.S. school finance. Figure 3, the derived tax bill for different households in the East community, vividly shows the issue of fiscal burden. The use of a property tax implies a low tax liability for households in small houses (small lots), but a high tax liability for households in big houses. As shown in Figure 3, the annual spending of about $\$ 1,951$ in the East School district is met with an annual tax liability of a small house of about $\$ 1,500$ but a corresponding liability of $\$ 2,700$ for each household in a big house. The households with the larger houses are effectively subsidizing the education of those with smaller houses. This observation identifies powerful incentives for communities to regulate the development of new land.

The fiscal disparities by households imply that there are larger incentives in the East district to exclude low income households with their lower consumption of quality housing. In the West, where school quality is less, the fiscal disparity is also reduced so that poor households pay about $\$ 1,120$ in taxes to pay for the school expenditure of $\$ 1,423$. A majority of the residents are low income households. Further, they attract a disproportionate share of high skilled households who have a low valuation of schooling. The predominance of low income and low valuation household in the West implies that they do not want to raise school spending in the West district. As a result, the majority in West would not want to exclude low income voters.

For the rest of the paper, we will study the impact of some alternative land use policies on the efficient provision of education and how successful they are in terms of excluding households that would impose a fiscal burden on the government. In all cases, we consider the case where the East imposes controls, while the West does not. 


\section{Land-use Controls}

We use this expanded locational choice model to analyze how a local government can exclude households by some land use controls. We consider alternative kinds of restrictions (which may or may not be permissible for use by any given jurisdiction, depending on state laws): zoning, lump sum tax, and fringe distance zoning. Each land use control is designed by the East in an attempt to exclude those imposing a fiscal burden on the high income residents. The key question is effectiveness of each kind of control and the implications for household location and school quality.

\subsection{Minimum Lot Size Zoning:}

To deal with the fiscal disparities, the local government in the East has an incentive to exclude households that impose a fiscal burden by introducing zoning regulations that set a minimum lot size (MLS) per household in residential land use, $s_{m}$. With this device, it hopes to eliminate the smallest houses, i.e., the ones imposing the largest burdens on the other residents. To determine the minimum lot size, the local government requires poor households in small houses to at least consume $s_{m}=4090$ square feet so that their contribution to the provision of public good would at least be about the expenditure per pupil in the East School District at the benchmark.

With minimum lot size zoning, the problem that the consumer in the East must solve is:

$$
\Psi\left(r, u_{i}, q_{j}, \tau_{j}\right)=\max _{s, z, l}\left\{\frac{Y_{i}(r)-z-w_{i} l}{\left(1+\tau_{j}\right) s} \mid U\left(\alpha_{i}, \eta_{i} ; q, s, z, l\right)=u_{i}\right\} \quad \text { subject to } s \geq s_{m}
$$

Observing that the utility function is concave, the bid-rent and bid-max lot size function under MLS regulation is given by

$$
\Psi^{*}(.)= \begin{cases}\Psi(.) & \text { if } r \geq r_{m} \\ \frac{Y_{i}(r)-\left(1+\frac{\gamma}{\delta}\right) w_{i}\left(\frac{\delta}{\gamma w_{i}}\right)^{\frac{\gamma}{\gamma+\delta}}\left(\frac{u_{i}}{q_{j}^{\alpha_{i}} s_{m}^{\eta_{i}}}\right) \frac{1}{\gamma+\delta}}{\left(1+\tau_{j}\right) s_{m}} & \text { if } r<r_{m}\end{cases}
$$




\begin{tabular}{|r|r|r|}
\hline \multicolumn{1}{|c|}{ Types } & West & \multicolumn{1}{c|}{ East } \\
\hline School Quality & 10.3 & 18.3 \\
\hline Tax Rate & $1.35 \%$ & $2.22 \%$ \\
\hline Skilled Low & 10 & 0 \\
\hline Skilled High & 0 & 30 \\
\hline Unskilled Low & 31.5 & 13.4 \\
\hline Unskilled High & 15.1 & 0 \\
\hline
\end{tabular}

Table 3: Equilibrium Distribution of Population and School Quality under Minimum Lot Size Zoning in the East

and

$$
s^{*}(.)= \begin{cases}s(.) & \text { if } r \geq r_{m} \\ s_{m} & \text { if } r<r_{m}\end{cases}
$$

where $r_{m}$ is the effective distance that is determined by the intersection between the lot size, s(.) curve and the horizontal $s_{m}$ line. (Consumers in the West solve the same problem except that $s_{m}=0$ ). Since the lot size curve is increasing in distance, the household would be constrained at $r<r_{m}$, and the bid-rent function for closer in properties becomes the bid-rent for the minimum lot size. As expected and seen in Figure 4, the bid-rent curve in the East is a straight line when households are constrained. The reason for this result is that the price of land increases as the distance to the city center decreases, and households respond to lower land prices by consuming less land. Once they reach the minimum lot size requirement, they cannot alter their land consumption, and it is linear. When they can alter their consumption, the bid-rent curve is convex.

In equilibrium, the East district continues to provide a better education, but there are significant locational changes compared to the benchmark case. A summary of the new equilibrium outcome is found in Table 3 and figures 4 through 6 . All Skilled Low Valuation (SL) and Unskilled High Valuation (UH) households flee from the East School District, which no longer best serves their needs. In addition, only a relatively small portion of Unskilled Low Valuation households stay in the East. All of the Skilled High Valuation households now reside in the East, which has become an exclusive city with fewer residents and higher 
average income. Many of the Unskilled Low Valuation households previously in the East stay in the East, but they are now forced to consume an amount of land, $s_{m}$ that is greater than the bid-max lot size without such a regulation. Thus, some fiscal burden of low income households remains in the East, but it is considerably reduced by the exclusionary zoning.

To explain the increasing amounts of annual tax liability of Skilled High Valuation Households at locations closer to the CBD in Figure 6, recall that they consume the minimum lot size and their tax liability increases towards the CBD due to increasing land prices. This result is different from Hamilton (1975). In a given community, both land consumption and tax liability differ across household types, while Hamilton finds that every household in a given community consumes the same amount of housing in equilibrium and pays the same amount of property taxes.

By extension, it is clearly possible to form a pure Skilled High Households community in the east by sufficiently raising the Minimum Lot Size (MLS) requirement level. This would make it unattractive for the Unskilled Low Valuation households, who would then prefer the West.

\section{$5.2 \quad$ Head Taxes}

The commonly-analyzed simple Tiebout model finances the local public goods with a constant tax for all individuals in a jurisdiction. Given the homogeneous nature of each district in the standard Tiebout model, the constant, or head, tax does not have much impact. In our model, however, the heterogeneity of districts in terms of income and equilibrium land consumption implies that the property tax and head tax will operate quite differently.

As should be clear, a head tax would eliminate the fiscal burden. ${ }^{11}$ We consider the possibility of applying a flat tax in the East School District, which is concerned with the

\footnotetext{
${ }^{11}$ While head taxes are not common in the U.S., they are used partially to finance schools in California. The introduction of a property tax limitation (Proposition 13) effectively set the property tax rate at a constant across the state. Individual districts may, with voter approval, establish a parcel tax that is the same for all residences in the jurisdiction regardless of their value.
} 


\begin{tabular}{|r|r|r|}
\hline \multicolumn{1}{|c|}{ Types } & West & East \\
\hline School Quality & 9.82 & 15 \\
\hline Property Tax Rate & $1.35 \%$ & $0 \%$ \\
\hline Skilled Low & 5.9 & 4.1 \\
\hline Skilled High & 1.1 & 28.9 \\
\hline Unskilled Low & 44.9 & 0 \\
\hline Unskilled High & 15.1 & 0 \\
\hline
\end{tabular}

Table 4: Equilibrium Distribution of Population and School Quality under Head taxes in the East

presence of the households that impose fiscal burdens on the local government, instead of the property tax. We analyze the implications of setting the head tax in the East at the expenditure per pupil in the benchmark.

As a result of the new policy, no unskilled workers wish to reside in the East (see Table 4 ). A few additional skilled low valuation households move the East, compared to the baseline, because of the increased accessibility from the East. But, with the fall in average property values in the West, the quality of schools declines in the West, again compared to the baseline. In total, fewer people now find the East to be an attractive residential location compared to the baseline, and its population is less.

\subsection{Reduced Fringe Distance}

An alternative land use policy frequently pursued is simply to deny new development within a city, thus making it more exclusive. For our modeling, we consider (urban) fringe zoning in which residential land use is restricted within a certain radius, $r_{f}$ from the city center. ${ }^{12}$ Here, $r_{f}$ is chosen to be eight miles. In order to reduce the fiscal burden of the baseline this policy would have to drive out unskilled households, because the land that is available for residential allocation in the East is smaller, allocated to the highest bidder, and skilled households can afford to bid more. In the new equilibrium, however, it is not so clear.

\footnotetext{
${ }^{12}$ Note that we think of this as maintaining restrictions on any expansions in the city, as is typical of many European cities. A policy to actually move the fringe in clearly reduces the value of property that was formerly residential and the owners would have to be compensated for such actions. Also, if the fringe moves out, so that the population expands, the new equilibrium can imply a reduced school quality for the East district.
} 


\begin{tabular}{|r|r|r|}
\hline \multicolumn{1}{|c|}{ Types } & West & \multicolumn{1}{c|}{ East } \\
\hline School Quality & 11.8 & 14.7 \\
\hline Tax Rate & $1.35 \%$ & $2.22 \%$ \\
\hline Skilled Low & 10 & 0 \\
\hline Skilled High & 0 & 30 \\
\hline Unskilled Low & 31.5 & 13.4 \\
\hline Unskilled High & 15.1 & 0 \\
\hline
\end{tabular}

Table 5: Equilibrium Distribution of Population and School Quality after Reduced Fringe Distance Zoning in the East

As shown in Table 5, the quality of education falls in the East compared to the baseline. All Skilled Low Valuation households move to the West School District, less high valuation households reside in the East, and more Unskilled Low valuation households live in the East school district. This policy is not effective at excluding households that impose a fiscal burden on the local government. Once again, skilled households subsidize unskilled households, and the problem of fiscal burden in the East remains.

To understand the failure of fringe zoning, recall that the spatial allocation of households is determined by the relative steepness of bid-rent curves. In the model, poor households have a steeper bid-rent curve, and they reside in locations closer to the CBD, leading to the failure of this policy to exclude the "right" households.

\subsection{Implications for School Quality}

The land use control policies all were motivated by reducing the fiscal transfers within a subset of the jurisdictions. A particularly interesting aspect of these policies is that they also have implications for the level and distribution of schooling. Specifically, by ending up with a different distribution of households, some of whom are constrained by the land use policies, the political support for schools changes in the two districts. Within each district, the combination of majority voting on tax rates and the heterogeneity of households within the districts means that a number of households typically are trading off school quality for accessibility and housing prices - and the educational outcomes will depend on the mix of households in the different communities. 


\begin{tabular}{|r|r|r|r|r|}
\hline Policy & West & East & Mean & Std \\
\hline Benchmark & 11.5 & 15 & 13.3 & 2.5 \\
\hline MLS Zoning & 10.3 & 18.3 & 14.3 & 5.6 \\
\hline Head Tax & 9.8 & 15 & 12.4 & 3.7 \\
\hline Reduced Fringe & 11.8 & 14.7 & 13.3 & 2.9 \\
\hline
\end{tabular}

Table 6: The quality of education across districts under various land use control regimes

We first look at the results for school quality by school district, as summarized in Table 6 and Figure 7. In general, the jurisdiction imposing land use controls can maintain as high or higher school quality for those households remaining in the district. However, the quality in the other jurisdiction (West) tends to decline. The resulting average quality of schools may or may not decline, but uniformly the variance in quality consistently increases.

With minimum lot size zoning, the gains in school quality in the East district are sufficient to offset the declines in the West so that average school quality increases. With the other policies, however, the average quality declines, implying that these land use controls work against public policy objectives of increasing quality and reducing variance.

Simply looking at the results by city, however, is incomplete, because the equilibrium outcomes of the different policies imply considerable movement across cities. An alternative summary is to investigate the school quality outcomes for the different families in our analysis, denominated by either income or valuation of schooling. Table 7 summarizes how the different types make out after the East district imposes the alternative land use controls.

The skilled households and the households that highly value schooling do better in terms of school quality with MLS zoning (compared to the benchmark case), and the skilled workers also improve school quality with the head tax. The reduced fringe zoning (growth limitations) lower school quality for both groups. The unskilled and the low valuation residents, who are generally simply reacting to the policies of the East, find that their school quality generally decreases - although any change is minimal with the reduced fringe zoning. 


\begin{tabular}{|l|c|c|c|c|}
\hline & \multicolumn{4}{|c|}{ Average School Quality } \\
\hline & Benchmark & MLS Zoning & Head Tax & Reduced Fringe \\
\hline Skilled Residents & 13.5 & 16.3 & 14.1 & 13.1 \\
\hline Unskilled Residents & 13.2 & 12.1 & 9.8 & 13.2 \\
\hline High Valuation Families & 14.1 & 15.6 & 13.1 & 13.7 \\
\hline Low Valuation Families & 12.6 & 12.3 & 10.2 & 12.7 \\
\hline
\end{tabular}

Table 7: The quality of education across household types under various land use control regimes.

\section{Conclusions}

The provision of educational services in the United States is tied to residential location. A range of active governmental policies have been aimed at altering both the level and the distribution of education across school districts, and it is clear that these policy deliberations must consider household reactions to policies and the alternative reasons why household choose a given location. ${ }^{13}$ This analysis focuses on the actions of individual jurisdictions to restrict the options available to households through exclusionary zoning and thus to improve their local fiscal situation. We embed our endogenous zoning choices within a simple model that recognizes that a given location offers both accessibility to employment and local schools. The quality of schools depends, however, on the preferences of local voters, something that could change in the aggregate with different policies. Putting these basic elements together, we can provide a general equilibrium solution to the household location problem that is useful for policy simulations.

We consider schools that are funded by property taxes. But, with heterogeneous communities, the presence of households purchasing different quality of homes can impose a fiscal burden on the local government, because a household in a small house pays a relatively small amount in taxes compared to school spending. Concerned with the fiscal burden of some households, the local governments may try to exclude those households paying less taxes than their cost of schooling by means of some exclusionary land use controls: minimum lot

\footnotetext{
${ }^{13}$ See, for example, the early study of Feldstein (1975) on state school finance options. More recent analysis incorporates accessibility into the analysis of governmental policy (Hanushek and Yilmaz (forthcoming)).
} 
size zoning, lump sum tax, or fringe distance(growth limitation) zoning.

We presume that the district with the highest income, the best school quality, and the largest fiscal discrepancies imposes a given land use control, while the other district does not. The resulting population distributions under the alternative policies differ substantially from the open market benchmark case. In terms of the quality of education provided, minimum lot size zoning within our parametrization actually increases average quality of education. However, as the mean quality of education increases, so does inequality, measured by the standard deviation. The other cases of permitting head taxes or of reduced fringe zoning (growth controls) tend to lower average school quality while also increasing the variance in quality across districts. It is generally true, however, that the upper income residents, who drive the restrictive zoning, can come out ahead in terms of school quality.

Our theoretical characterization of the equilibrium outcomes is of course dependent upon the specific utility functions and calibration of the model. Alternative calibrations can obviously lead to different results. The important message from our calibrations is, however, that the simplest models of locational choice - ones dependent on just the provision of differing amounts of the local public good - are likely to misstate the locational outcomes and the nature of public good provision. Specifically, models that lead to perfect sorting of households across communities, à la Tiebout (1956), are likely to misrepresent the outcomes that will result from local policy changes. Moreover, the general equilibrium nature of housing decisions means that the actions of households in one jurisdiction spill over into other jurisdictions, leading to changes not only in the structure of housing prices but also in the overall provision of public goods. These can be very significant when there are limited numbers of jurisdictions as in our modeling here. 


\section{References}

Altman, J.L. and Desalvo, J. (1981). Tests and extensions of the Mills-Muth simulation model of urban residential land use. Journal of Regional Science 21: 1-21.

Bertraud, Alain, and Stephen Malpezzi. 2003. " The Spatial Distribution of Population in 48 World Cities: Implications for Economies in Transition " Working paper.

Calabrese, Stephen, Dennis Epple, and Richard Romano. 2007. "On the political economy of zoning." Journal of Public Economics 91, no. 1-2 (February): 25-49.

de Bartolome, Charles A. M., and Stephen L. Ross. 2003. "Equilibria with local governments and commuting: Income sorting vs income mixing." Journal of Urban Economics 54:1-20.

Durlauf, Steven N. 1992. "A Theory of Persistent Income Inequality" Journal of Economic Growth 1:75-93.

Cassidy, Glenn, Dennis Epple, and Thomas Romer. 1989. "Redistribution by local governments in a monocentric urban area." Regional Science and Urban Economics 19, no. 3 (August): 421-454.

Epple, Dennis, Radu Filimon, and Thomas Romer. 1988. "Community development with endogenous land use controls." Journal of Public Economics 35:133-162.

Epple, Dennis, Radu Filimon, and Thomas Romer, 1993. "Existence of Voting and Housing Equilibrium in a System of Communities with Property Taxes." Regional Science and Urban Economics 23:585-610.

Evans, A.W. 1999. "The land market and government intervention" In Handbook of Regional and Urban Economics, edited by Paul Cheshire and Edwin S. Mills. Amsterdam: North Holland.

Feldstein MS. 1975. Wealth neutrality and local choice in public education. American Economic Review 65: 75-89

Fernandez, Raquel, and Richard Rogerson. 1996. "Keeping people out: Income distribution, zoning, and the quality of public education." International Economic Review 38,no.1:23-42.

Fujita, Masahisa. 1986. "Urban land use theory." In Location Theory, edited by J.J. Gabszewics, Jacques-François Thisse, Masahisa Fujita and U. Schweizer. Chur, Switzerland: Char:73-149.

Hamilton, Bruce W. 1975. "Zoning and property taxation in a system of local governments." Urban Studies 12:205-11. 
Hanushek, Eric A. 1996. "School resources and student performance." In Does money matter? The effect of school resources on student achievement and adult success, edited by Gary Burtless. Washington, DC: Brookings:43-73.

_. 2003. "The failure of input-based schooling policies." Economic Journal 113, no.485 (February):F64-F98.

Hanushek, Eric A., John F. Kain, Jacob M. Markman, and Steven G. Rivkin. 2003. "Does peer ability affect student achievement?" Journal of Applied Econometrics 18, no.5 (September/October):527-544.

Hanushek, Eric A., and Kuzey Yilmaz. 2007. "The complementarity of Tiebout and Alonso." Journal of Housing Economics 16, no.2 (June):243-261.

—. 2011. "Urban education, location, and opportunity in the United States." In Oxford Handbook of Urban Economics and Planning, ed. N Brooks, K Donaghy, G-J Knaap, pp. 583-615. Oxford: Oxford University Press

forthcoming. "Household location and schools in metropolitan areas with heterogeneous suburbs: Tiebout, Alonso, and government policy." Journal of Public Economic Theory

Hanushek EA, Lindseth AA. 2009. Schoolhouses, courthouses, and statehouses: Solving the funding-achievement puzzle in America's public schools. Princeton, NJ: Princeton University Press

Hanushek, Eric A., Sinan Sarpca, and Kuzey Yilmaz. 2011. "Private schools and residential choices: accessibility, mobility, and welfare." B.E. Journal of Economic Analysis \& Policy (Contributions) 11(1): article 44.

Rose, Louis A. 1989. "Topographical constraints and urban land supply indexes." Journal of Urban Economics 26 (3), pp. 335-347

Sukkoo, Kim. 2007. "Changes in the Nature of Urban Spatial Structures in the United States, 1890-2000,” Journal of Regional Science 47 (2): 273-287.

Magliocca, Nicholas, Virginia McConnell, Margaret Walls, and Elena Safirova. 2012. "Zoning on the urban fringe: Results from a new approach to modeling land and housing markets." Regional Science and Urban Economics 42, no. 1-2 (January): 198-210.

Mills, Edwin S., and Bruce W. Hamilton. 1989. Urban Economics. Fourth Edition ed. Glenview, IL: Scott, Foresman and Company. 
Mills, Edwin S. 1972. Studies in the Structure of the Urban Economy. Washington, D.C.: Resources for the Future, Inc.

Nechyba, Thomas J. 2006. "Income and peer sorting in public and private schools." In Handbook of the Economics of Education, edited by Eric A. Hanushek and Finis Welch. Amsterdam: North Holland:1327-1368.

Pack, Howard, and Janet Rothenberg Pack. 1977. "Metropolitan fragmentation and suburban homogeneity." Urban Studies 14:191-201.

_. 1978. "Metropolitan fragmentation and local public expenditures." National Tax Journal 31:349-362.

Persky, Joseph J. 1990. "Suburban income inequality: Three theories and a few facts." Regional Science and Urban Economics 20:125-137.

Quigley, John M., and Larry A. Rosenthal. 2005. "The effects of land use regulation on the price of housing: What do we know? What can we learn?" Cityscape 8, no. 1: 69-137.

Tiebout, Charles M. 1956. "A pure theory of local expenditures." Journal of Political Economy 64, no.5 (October):416-424.

Yinger, John. 1982. "Capitalization and the theory of local public finance." Journal of Political Economy 90, no.5 (October):917-43.

. 1985. "Inefficiency and the median voter: Property taxes, capitalization, heterogeneity, and the theory of second best." In Perspectives on local public finance and public policy, edited by John M. Quigley. Greenwich, CT: JAI Press:3-30. 
Fig 1: Monthly Gross Rent per acre (East District)

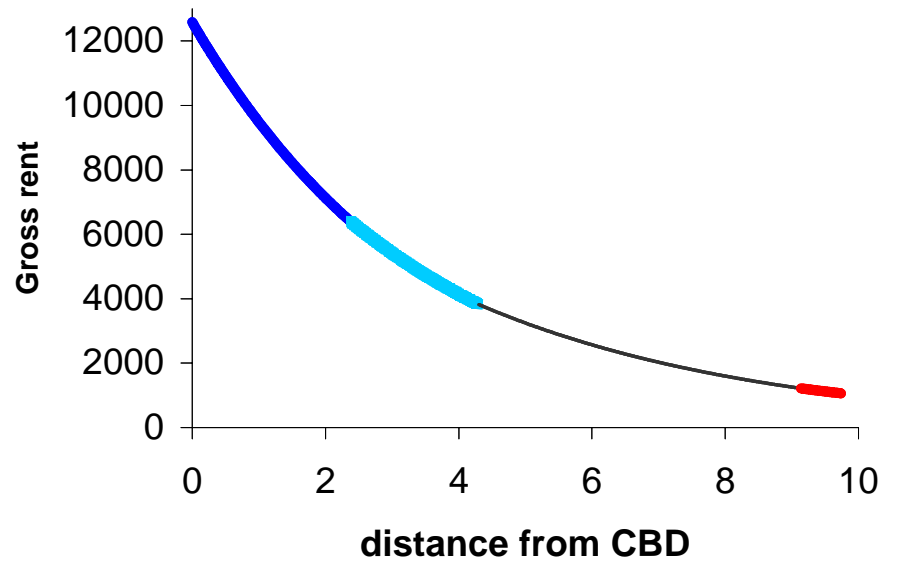

Unskilled low(UL)

Unskilled high(UH)

Skilled low(SL)

Skilled high(SH)

Fig 2: Lot Size (East District)

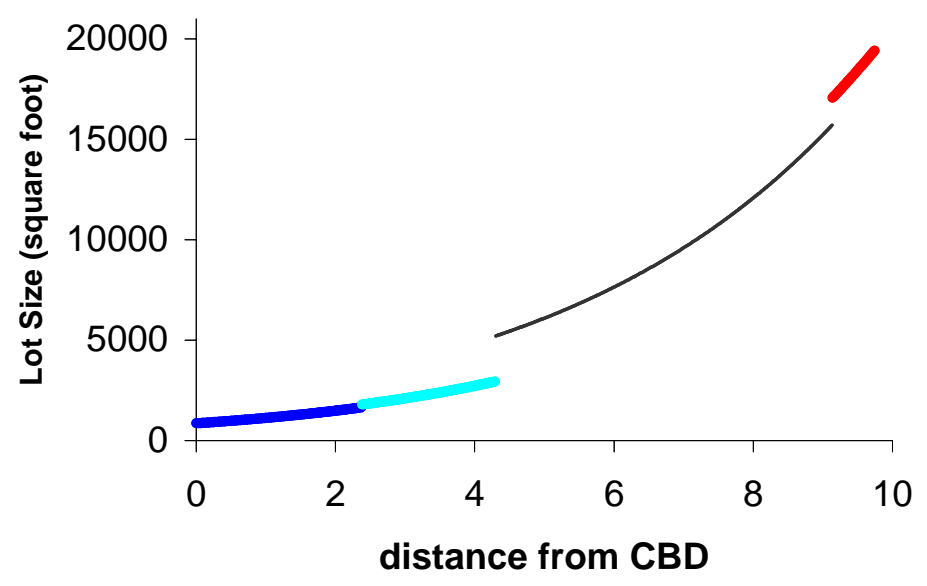

Unskilled low (UL)

Unskilled high (UH)

— Skilled low (SL)

Skilled high (SH)

Fig 3: School Expenditure and Taxes Paid (East District)

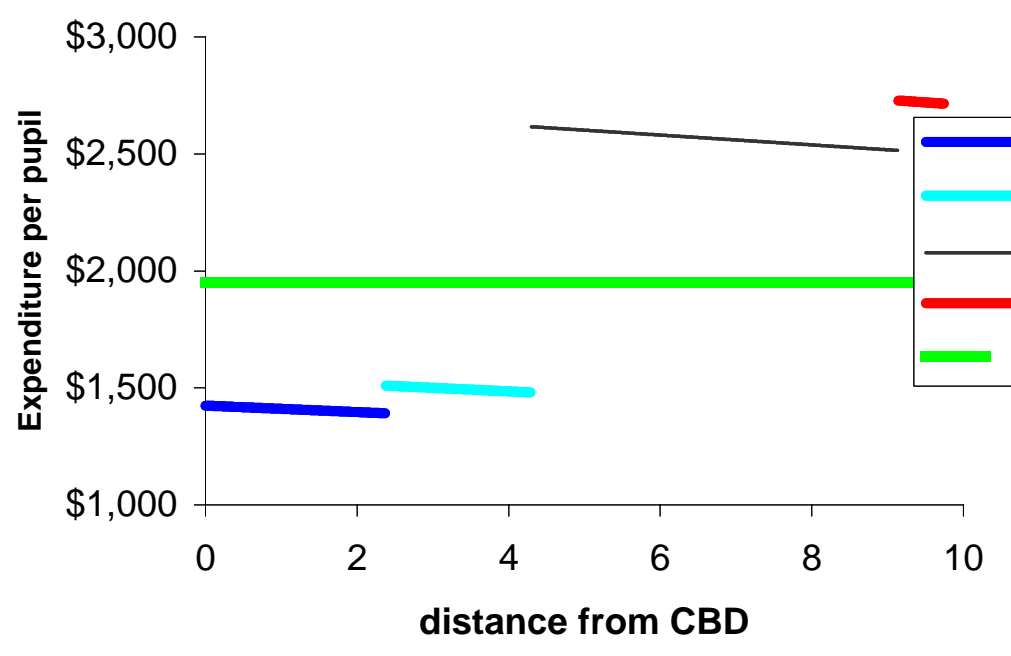

Unskilled low (UL)

Unskilled high (UH)

Skilled low (SL)

Skilled high (SH)

School Expenditure 
Fig 4: Monthly Gross Rent per acre with MLS Zoning

(East District)

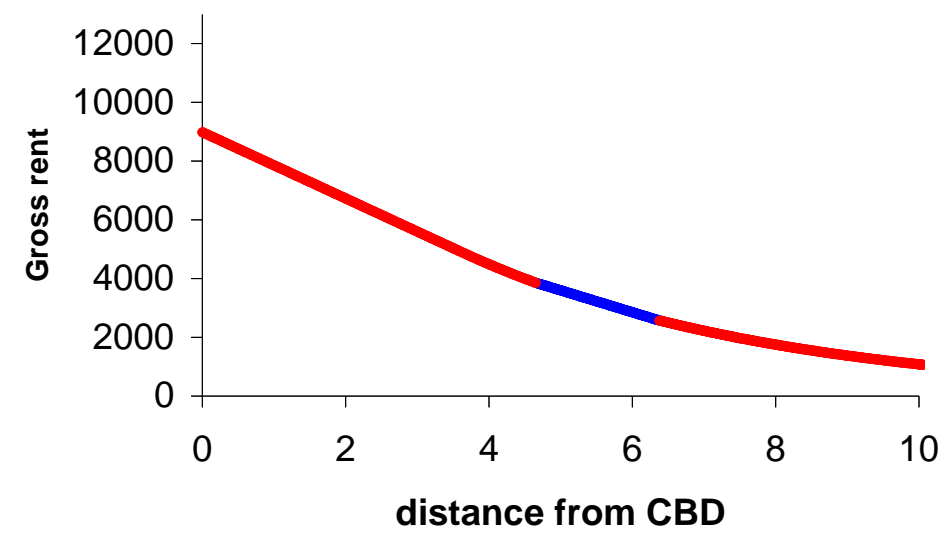

Unskilled low (UL)

Skilled high (SH)

Fig 5: Lot Size with MLS Zoning (East District)

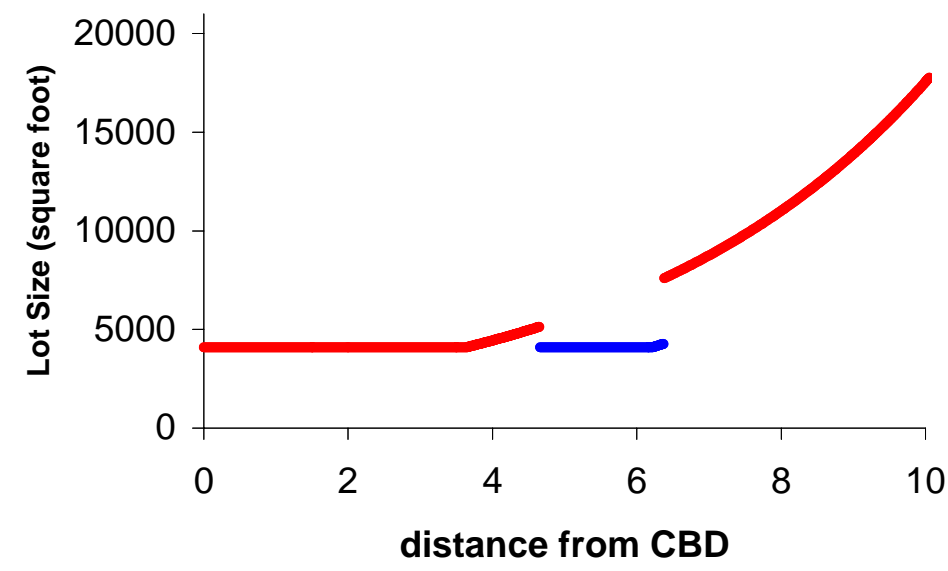

Unskilled low (SL)

Skilled high (SH)

Fig 6: School Expenditure and Taxes Paid with MLS Zoning (East District)

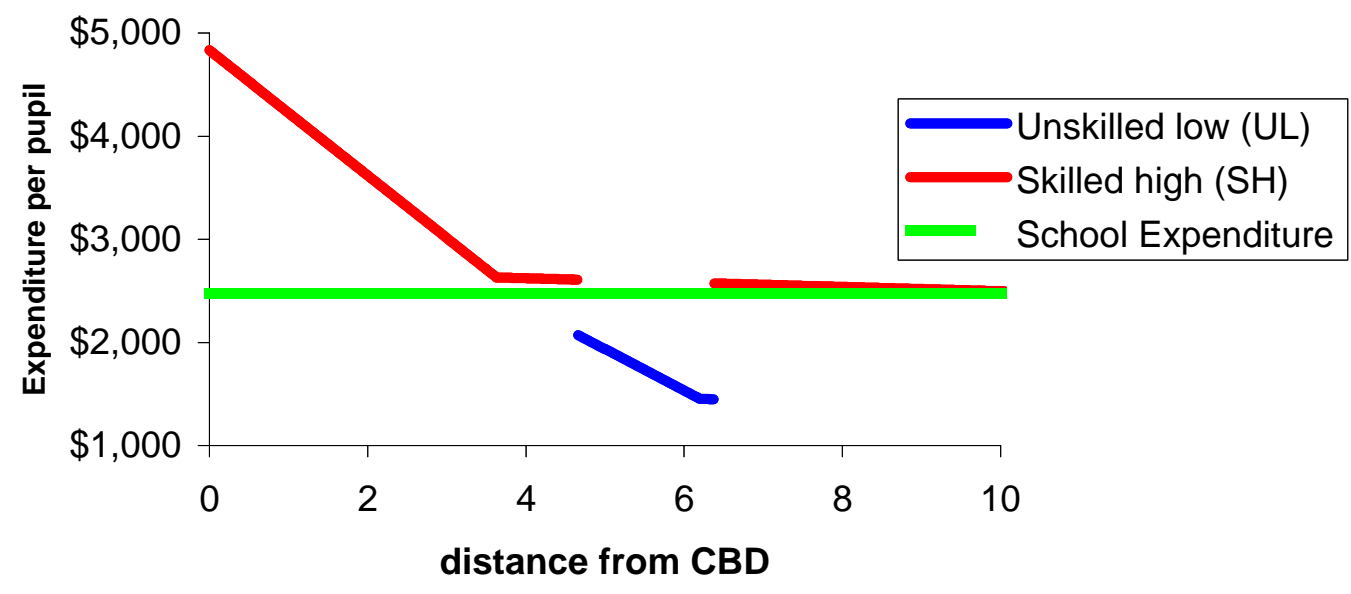




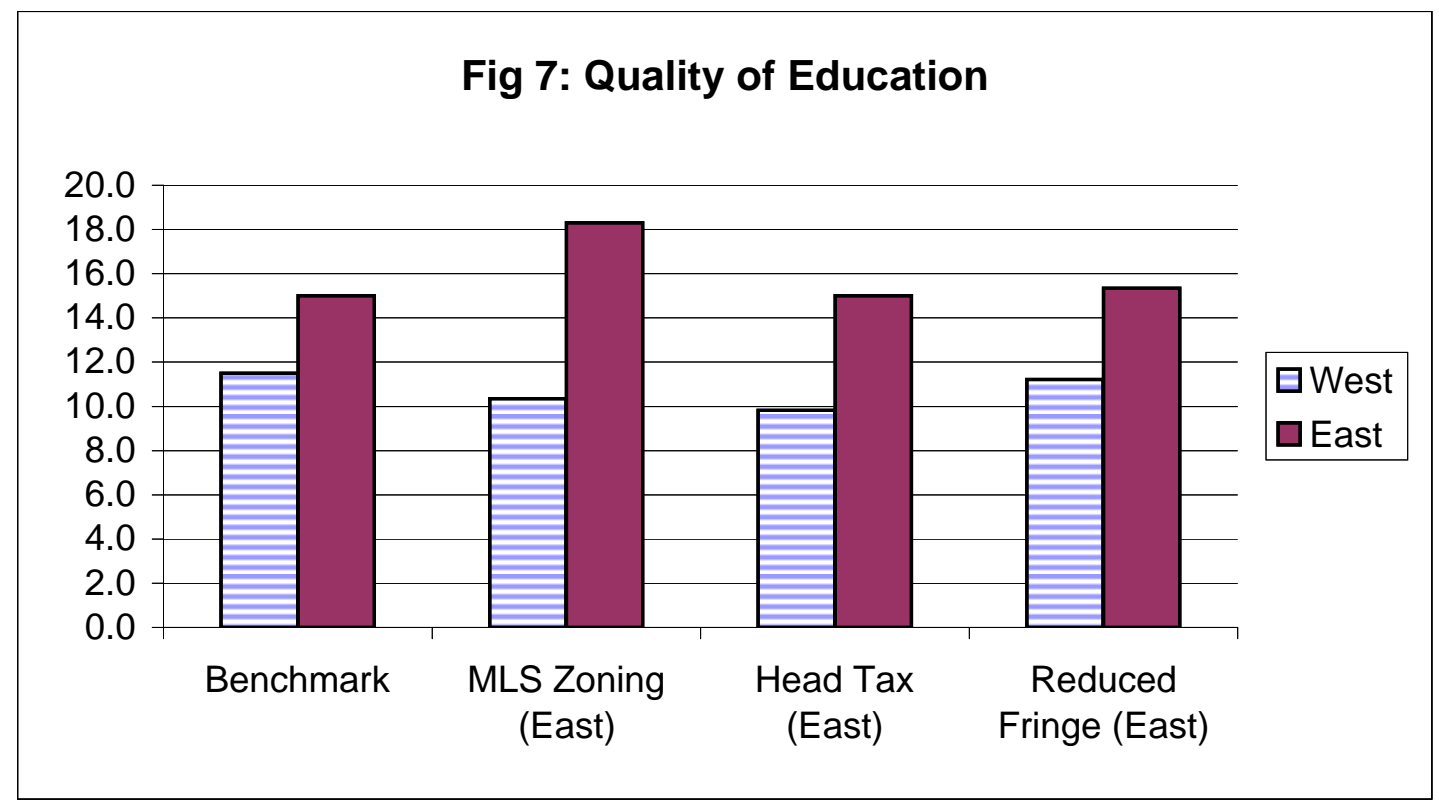

